\title{
EchoGéo
}

29 | 2014

The Political Ecology of Conservation and

Development Territories

\section{Marine Protected Areas: Territorializing Objects and Subjectivities}

Fletcher Chmara-Huff

\section{OpenEdition}

Journals

Electronic version

URL: https://journals.openedition.org/echogeo/14040

DOI: $10.4000 /$ echogeo. 14040

ISSN: 1963-1197

Publisher

Pôle de recherche pour l'organisation et la diffusion de l'information géographique (CNRS UMR 8586)

Electronic reference

Fletcher Chmara-Huff, "Marine Protected Areas: Territorializing Objects and Subjectivities", EchoGéo

[Online], 29 | 2014, Online since 18 November 2014, connection on 31 July 2021. URL: http://

journals.openedition.org/echogeo/14040 ; DOI: https://doi.org/10.4000/echogeo.14040

This text was automatically generated on 31 July 2021.

EchoGéo est mis à disposition selon les termes de la licence Creative Commons Attribution - Pas d'Utilisation Commerciale - Pas de Modification 4.0 International (CC BY-NC-ND) 


\title{
Marine Protected Areas: Territorializing Objects and Subjectivities
}

\author{
Fletcher Chmara-Huff
}

1 Marine Protected Areas (MPAs) provide a unique case for looking at territorialization. Oceans, unlike terrestrial territories, offer new challenges for exploring the ways that power over space can be configured. While this paper draws from a wider analysis of a specific case in the Bahamas that will be forthcoming in other papers, this paper seeks to draw attention to theoretical considerations about territorialization by using MPAs as a particular form, rather than focus on the specific case. I will argue below that the imposition of territory by the state, through conservation policy in the ocean, is one of many possible drivers of alternative territorialities. These territorialities appear outside of terrestrial state formations, leading to unstable territorializations in the ocean that can then be contested, adopted, or ignored. This suggests that spatial conservation practices in the ocean provide an opening for a spatial politics that may not appear so readily in studies of terrestrial conservation, as terrestrial forms of conservation are always within the (mistakenly) assumed container of a state (Agnew, 1994). The implication of these claims is that consideration of MPAs can add to the theorization of territorialization, precisely because MPAs are not always fully within the matrix of state territory.

2 This claim should not be surprising, for there is a large body of literature that suggests that rather than a state limit, territory is less of a thing and more of a symptom (Gottmann, 1973), or else the result of human territoriality in it various forms (Sack, 1986). Conservation territory in particular is noteworthy in that it is control of spaces for control of resources and people, regardless of whether the resources in question are present (Johnsen et al., 2004;Vandergeest and Peluso, 1995, Sack, 1986). Recent scholarship on territory has suggested that it is the intersection of technologies of governance and measurement of space, leading to a formulation that could be described as power over space (Elden, 2009). Yet power can also be theorized as diffuse 
from a Foucaultian perspective, or else always being resisted and therefore deterritorialized (Deleuze \& Guattari, 1987). Therefore, it is important to ask with any territorialization, and this includes conservation areas, what struggles take place around its formation, and whether the creation of a territory may call into being a resistance and accompanying re- or de-territorializations. While many political ecologists have called attention to the problems of spatial forms of conservation as takings by the state (cf. Neumann, 1998; Robbins, 2003; Brockington, Duffy and Igoe, 2008), I am proposing that we need to consider conservation areas as territorial formations, and attend to the ways that power of space is transformed by ecological concern.

\section{Why Marine Protected Areas?}

3 The ocean is fertile ground for study, in part because it is historically weakly territorialized (Steinberg, 2001), and because in recent years many scholars have declared the ocean to be in crisis. Recent models of fishery sustainability have predicted a turn for the worse, suggesting a potential worldwide collapse of $90 \%$ of the stocks by 2048 (Worm et al, 2006). In light of such dire predictions, experts are renewing their calls for fishery management both in the U.S. (Safina et al, 2005), and the rest of the world (Beddington, Agnew and Clark, 2007). Scholars propose numerous strategies to manage fisheries and improve health of the oceans, the most prominent of which all include "enclosing" oceans in some way (Mansfield 2007a, 2007b). One tactic of enclosure is to privatize fisheries through the use of individual transferable quotas. These quotas give fishers the right to target a specific stock, or the direct establishment of rights to exploit specific areas of seabed, in essence creating a property right in the sea (Gordon, 1954). These types of quota based rights are seen primarily in the more developed world (Hannesson, 2004; Costello, Gaines and Lynham, 2008).

The other dominant strategy for protection of fisheries is creation of Marine Protected Areas (MPAs), which set aside spaces for conservation in the sea and exclude extractive activities. Recent scholarship has suggested that each strategy, whether a quota or spatialized restriction, has prerequisites for success. A mismatch may occur when a conservation strategy is deployed without considering preexisting social structures that will affect the outcomes (Mora et al, 2009; Stoffle et al, 2010). MPAs often assume a lack of social relations in the sea, and overlay them within a scientific matrix of expertise; this expertise determines which spaces should be set aside according to experts in the field of marine conservation, often from a biological science perspective. MPAs can then be read as spaces which scientists, as designers of conservation, are withdrawing from public use, regardless of historical and present use values.

MPAs have become a particularly prominent conservation strategy in the developing world due to minimal start-up cost, and many scholars consider networks of MPAs the best approach to protect a dwindling resource for nation-states and the world (Roberts et al, 2001; National Research Council, 2001; Nowlis and Friedlander, 2004). Some scholars argue that there are limits to the effectiveness of spatial conservation for some species (Kaiser, 2005), due to a scalar mismatch in the definition of ecosystem (Spieles, 2010). Yet, MPAs are a popular form of fishery conservation because it is claimed that they seek to replenish fish stocks by considering the ecosystem, rather than an approach based on the maximum sustainable yield of a targeted species, which may not 
consider secondary effects and trophic levels. The thinking behind MPAs is that if one manages specific ecosystem spaces based on benthic ecosystem conditions, instead of directly managing target species through the exclusion of fishers or certain fishing activities, a healthy ecosystem will result, increasing the biomass of targeted species (Sobel and Dahlgren, 2004).

6 Much conservation literature suggests that in order for conservation projects to succeed, negotiating the support of local people is essential (Pretty and Ward, 2001; McCay and Jeantoft, 1998, National Research Council, 2001; Eliott et al, 2001; Christie et al, 2003). While policy makers have started to try to include people in conservation decisions, one criticism of these approaches is that they put ecosystem variables first, and then add a limited number of social variables (Nietschmann, 1997; Mehta and Kellert, 1998). This means that significant social factors that contribute to conservation decision-making and responses may be overlooked (Stoffle et al., 2010).

7 This logic of marine management is in many cases dictated by ways of thinking that emphasize fish as a resource for exchange in markets, rather than as a resource that people utilize. Further, this is compounded by using a thin conception of 'community' (Agrawal and Gibson, 1999; Agrawal, 2000) that overlooks the complex social relations within and between communities and the larger socio-political world; these multiscalar relations make it difficult to solve conservation problems on a strictly localized scale. While the incorporation of social variables in conservation design appears to be a response to these earlier critiques, they fall short precisely because of a limited number of variables in practice (Stoffle et al., 2010). This lack of complexity in the social factors of MPA creation then compounds the question of how much sound ecology actually fits into the models of ecosystem variability, suggesting that present approaches are limited in their responses to both a changing ecology, and changing social variables.

\section{Social Science Approaches to Conservation}

8 Social scientists have critiqued conservation using a diverse assemblage of theoretical standpoints to argue that conservation is in fact a series of social relations, and may have little to do with "nature." Johnsen et al. (2004) draw on the work of Donna Haraway (1991), to argue that marine conservation efforts form a techno-scientific network of relations and connections that recreate the ocean as a "black box". Other scholars have argued that conservation efforts produce spaces of exclusion, and that these are therefore political spaces (c.f. Neumann, 1998; Vandergeest and Peluso, 1995; Ogden, 2011). In his writings on the state, Lefebvre noted that in addition to the domestic spaces of human activity, nature is also always political for it supports human activity (Lefebvre, 2009a). Similarly, political ecologists have argued for years that conservation is entangled in social relations, capitalist accumulation, and the disempowerment of people Neumann, 1998; Robbins, 2004). Territorial spaces, and also counter-territorializations, are therefore produced by conservation efforts caught up in struggles of power over space (Ogden, 2011). While all of these authors begin from different theoretical standpoints, they are essentially questioning the ways in which the "nature" of the non-human world, and therefore its protection, is in fact caught up in social relations that must be attended to (Catree, 2005).

9 As a spatialized strategy, MPAs are subject to the same critiques as their terrestrial conservation counterparts. Ecological reserves are a common and contested practice on 
land as governance is transformed from customary to state control (Neumann, 1998; Igoe, 2004; Brockington, Duffy and Igoe, 2008). The effects of marine conservation as territorialization have been addressed to some degree within the MPA literature, which notes that reserves have been contested due to a "fencing of the sea" (National Research Council, 2001; Steinberg, 2001; Mansfield, 2004). By attempting conservation through a territorial tactic, reserves adopt a spatially fixed preservationist stance, while arguing towards a general environmental concern (Rome, 2001), within a technoscientific network of relations and connections "...linking together nature, society, technology, science, markets, and policy in new ways" (Johnsen et al., 2004). To this list I would add the territorialization of the ocean, a process that produces new spatial practices, and following Lefebvre (1991), new representations of space. MPAs differ from historical marine management strategies by changing the spatial configuration of the sea. It moves from what some people perceive as an "open access regime" that is vulnerable to a tragedy of the commons (Hardin, 1968; Gordon, 1954) into a territorialized network of spaces with different levels of access (Ribot and Peluso, 2003) that expands state power into new domains (Vandergeest and Peluso, 1995). Like landbased conservation areas, MPAs are territories deployed as total exclusionary spaces. This exclusion is promoted by the state, suggesting an accumulation by dispossession that changes the livelihood strategies of stakeholders (Harvey, 2003).

\section{Resistance to State Conservation: Indigenous Rights}

10 As noted above, the ocean has long been viewed as a vast and weakly territorialized space (Steinberg, 2001), especially before the adoption of the UN Convention on Law of the Sea in 1982 (Glassner, 1990). Critical geographic scholarship on marine management suggests that the first step in managing the oceans as a national resource works by enclosing the space of the oceans, and transferring territorial control of the ocean to the state (Mansfield, 2001, 2004). State control of the oceans then works in ways that transform the access rights of users, often with little consideration of how fishers themselves spatially may practice extraction of marine resources (St. Martin, 2001, 2006). Further, it overlooks whether they have prior claims to territorial control of extraction spaces (Nietschmann, 1997), claims which may work to support community- based management regimes. Thus, it is important to ask to what ends and whose benefit are reserves created, and what responses will this new territorialization evoke from non-state stakeholders and actors.

The pioneering work of Nietschmann $(1973,1997)$ with the people of the Miskito Coast of Nicaragua suggests that people may have claims to resources and territorial spaces prior to the creation of the state-owned fishery resource. This is not the only example of this kind of claim (c.f. Stoffle, 1986, 2001; McCay and Acheson, 1987; McCay, 1987). Nietschmann (1997) documents the historical claims to Customary Marine Tenure (CMT) along the Miskito Coast and the ways in which coastal peoples have tried to secure that tenure over time ${ }^{1}$. Early in the essay, Nietschmann claims that conservation, as practiced by International NGOs, is a colonial practice. The people of the Miskito Coast are therefore contesting conservationist efforts as resistance to threats to their sovereignty (territory) and their livelihoods related to reefs that they 'own,' (tenure). Further, the people have maintained the reefs in question as healthy ecosystems through a conservation ethic. The operations of conservationist 
organizations in the area are treated by the people who hold CMT as the latest in a series of threats after wars and foreign exploitation of the fishery, and Nietschmann clearly supports the right of the people to fight off these threats.

In fact, the purpose of his 1997 paper is explicitly a political project. The reason that Nietschmann is weaving together the stories of fishing practice, wars, and resource exploitation is to argue for the rights of indigenous people to establish a de jure territory in the ocean for their explicit use. Further, he argues that the people are the historic stewards of the area and therefore deserve to continue their relations with the ocean. The dynamic that he reveals is that conservation policy, as designed by outside conservationist actors is colonial in the ways it seeks "sustainability" by producing conservation areas that exclude local people, while also providing room for economic development of the ocean by creating a commercial fishery. He is arguing that the conservation projects will be resisted because of the failure to recognize existing claims to the conservation areas. MPAs are political projects in Nietschmann's analysis, for whoever controls the space of the MPA has an established right to the organisms within, and this right can be used to integrate with, or reject, the capitalist system.

While I am convinced of the merits of Nietschmann's argument, I wish to point out that the way in which he makes his case is itself available for critique. Nietschmann's presentation suggests that the issues of conservation areas on the Miskito Coast are in many ways similar to the arguments against park creation on the land (Neumann, 1997, 1998; Robbins, 2004). Nietschmann's case is included in a volume that argues for indigenous homelands as "...often the last remaining places of rich wildness and biological diversity" (Stevens, 1997, 1, emphasis mine). This human ecology model that puts the people 'back into' a wild nature (Cronon, 1995) arguably simplifies socionatural interactions and is in danger of reifying the "ecological native" myth (Krech, 1999).

The notion that indigenous people are stewards has been deployed within the bounds of cultural ecology to argue that humans are a part of nature, and therefore they must be accounted for. Indeed, certain ecologists have noted that humans are themselves part of ecosystems and in some cases are important capstone predators (Castilla, 1993; Berkes, 1999) or should actively work to make the nature they want to see (Sapp, 1999). There is also evidence that people can be produced as environmental subjects when they are thrust into the role of being the wise stewards who possess 'traditional ecological knowledge' as this knowledge is incorporated into hegemonic discourses (Sletto, 2005; Agrawal, 2005), leading to positive ecological outcomes. This 'environmentality' can then be deployed to reassert power relations for people who had seen their standing weakened by environmentalist discourses that often trope humans as negative ecological forces. So while I am cautious that is possible to read the case of the Miskito as a story that reinforces the myth of the ecological native, I am also aware that local and traditional ecological knowledge can and does have positive effects in many cases of marine conservation (Mora et al., 2009).

However, Nietschmann glosses over a factor that makes marine conservation debates different, and that is the history of power relations in the sea. Steinberg (2001) traces the ways in which the oceans have gradually been enfolded into state territory (see also Mansfield, 2004) with large portions still remaining Mare Liberum under international law. While Nietschmann argues for a move towards a territory on behalf of an indigenous people, he fails to address the obstacle of the imaginary of the sea as empty 
space. Due to the modern political process, lines are now being drawn on the map of the ocean that fill the space through claims such as Exclusive Economic Zones that represent the power of the state. Even then, the map still only has a new borderline, and often no features within the new border save shorelines.

In fact, the fishers for whom Nietschmann advocates have never been on the map, they are Homo nullius. This is not limited to this particular case, as it is common in many marine management decisions (Pannell, 1996). Human territories in the ocean, while a spatial practice, have been rendered invisible through the mapping of the sea as a blue field (Steinberg, 2001). Arguing for their reappearance in an empty spatial imaginary is easier said than done, as ocean territory is now enforced by the state as a result of treaties between sovereign nation-states.

17 Arguably, the fish and turtles that fall within the boundaries of the reserve that Nietschmann supports are not fully present either, because they are fugitive resources that may not even be present (Johnsen et al., 2004). Our mapping practices render the ocean as representationally opaque to us, and our ecological understandings of it tend to be oriented towards the extraction of useful species, rather than a robust understanding of an ecology (Wolf, 2003). When the argument of rightful control due to a CMT is deployed, we are presented with a political ecology that is full of politics, but thin on ecology (Walker, 2005; Zimmerer, 1994). Further, spatial reconfigurations like MPAs or customary marine tenure posit a nature that can be contained by negatively bounding human behavior within a produced space. This however is a false conception because unlike on the land, "nature" cannot be contained under the sea by erecting barbed-wire fences. Rather than containing fish, MPAs, even ones that seek CMT rights, work to keep out people.

What Nietschmann offers is instead a productive movement of the debate from conservation of 'resources' to a discussion of politics and power relations as the necessary frame to understand conservation debates, because resources are part of the political economy. Further, he exposed the rhetoric of community-based conservation as put forth by NGOs for what it was, a way to govern associated communities within a system that seeks to colonize space.

While he makes a good case for conservation based on the actually existing communities of the Miskito Coast, there are two further problems. The first has to do with the possibility that his 'wise stewards' may shift their extraction patterns. While this is unlikely due to a strong environmental ethic among the Miskito people according to Nietschmann (1973), work with other traditional people's has shown this is a possibility (Stoffle, 2001). Nietschmann avoids this question in his 1997 chapter by addressing the problem from an entitlement framework (Johnson, 2004). However, this is also a political ecology that fails to address ecology in a robust fashion. Despite misgivings about the lack of ecology in Nietschmann's argument, Sletto (2005) suggests that one answer might be that empowering people to protect spaces reinforces ecologically sound behavior.

The second problem I discern with Nietschmann's approach is a conception of customary tenure as a proxy for community property. The empirics of the case on the Miskito Coast show well defined reef territories that are tied to indigenous communities as community property (Nietschmann, 1997). However, the category of Indigenous itself presents a problem in that it homogenizes both the questions of who is local and what other categories exist to describe community composition (age, 
gender, class, ethnicity, etc.) in a problematic fashion (Neumann, 1997; Agrawal, 2000) that glosses over competing claims to resources.

St. Martin $(2001,2006)$ explores this question in his studies of fishers in the northeastern US. The complexity that St. Martin finds in his case of trying to locate community suggests that the perhaps community property is a problematic concept that fails to account for the wide uses and extraction patterns in the ocean that could lead to broader use claims. Further, because control of the oceans is assigned to the state under the UN Convention on the Law of the Sea, it logically follows that the politics of the ocean then depends on accounting for the nation. Fishers from distant communities may claim a portion of the sea under changing political circumstances, as a community with customary rights accorded by citizenship in the nation-state. St. Martin's case suggests that the idea of a 'local' fishery is an oversimplification that cannot account for the diversity of spatial practices of fishers. The sea, as an empty but simultaneously territorialized space, has a diversity of patterns and practices in extraction. This then means that any areal marine policy will have to account for this diversity, or risk social violence against a fisher who is thereby excluded. Indeed, it has been shown that spatial strategies can do just that when they effect rights to the exclusion of other actors (Mansfield, 2007b).

\section{The Power of Ocean Territory}

In arguing for spatial strategies for marine conservation, both marine scientists who support MPAs and social scientists advocating for conservation management that incorporates local people are arguing for a spatial solution to the problems of overextraction. Ocean territorialization as a political practice has rarely been addressed in existing social science on MPAs, in no small part due to a tendency to focus narrowly on discrete social variables in order to create predictive models (Stoffle and Minnis, 2007; National Research Council, 2001; Stoffle et al., 2010; Broad and Sanchirico, 2008), or address policy development on the global or national scale (Mansfield, 2001; St. Martin, 2006). Further, while the goal of these studies is for the purpose of accessing fish as a resource, fish are little more than a series of organisms to be fought over. In order to create an MPA, you need people to exclude, and an entity to have the right of exclusion as the enforcer of territory; the ecology is secondary. The complete ecology of oceans is difficult to capture, because any spatial solution encounters only space, with ocean life that cannot be enclosed by fences and about which little is known (Acheson, 2006), leaving only humans and social variables to put into the formula.

The continual reification of territory is something that cannot be theorized away, and we therefore should attend to the ways in which conservation is played out as a spatial strategy, and people's tactics of resistance. Attending to the production of conservation space as territories allows consideration of the ways these territorializations operate on specific scales in relation to others. In her critique of the descaling of the state and the alleged process of "glocalization," Mansfield discovers that territory and the state have changed form. Through reregulation, and therefore re-territorialization, the territorial state has not disappeared, but only modified the sites of its power relations (Mansfield, 2005). While some have argued that the national state is fading away as a scale of analysis, it is important to remember that states can be both conservative and 
transformative, and are therefore adaptable. Rather than disappearing, they are changing their use of territorialization to capture both moments, and there is evidence to suggest that they always have been, depending on whether they are faced with stability or crisis in the social order (Clark and Dear, 1984; Gottmann, 1973).

I want to suggest that if we are to take the notion of territorialization and its political potential to both protect ocean resources and resist territorial takings, we should attend to Sletto's (2005) work on the Nariva Swamp. By thinking about how local power/knowledge configurations are both incorporated by the state in seeking to control a conservation area, and in turn provide new political possibilities for control by local inhabitants, Sletto has outlined the ways that the discourses of rightful control over a space provides people with new political possibilities. The process of becoming the historically constituted managers of a conservation area, and its resultant territorialization, has become a site of resistance to state power. The subjectivity of local people to the discourse of conservation as good stewards, and resistance through adopting these discourses both changed their behavior and gave them power to control both the space and the discourse. Rather than an imposition of state power, the Narriva Swamp has become a site of re-territorialization.

What can we learn from this example? I am claiming that a territorialization such as this one leads to liberatory moments that can be rethought through the analytic lens of territorialization as political movement. Too often in the literature, territory is surrendered to state power, with attention paid to the juridical nature of territory. However, the premise that territoriality is a behavior that exists in both groups and individuals (Sack, 1986), suggests to me that perhaps territory is never exclusively the domain of the state. The debates about the opposition between property rights and eminent domain exemplify the tension between state territory and individual territories, similarly struggles over control of natural resources on "public" lands complicate the relation between territory of the state and society. I wish to suggest that these moments of tension between the state and society offer a moment best described as territorialization driven by political struggle. While territory is always permeated by power relations (Elden, 2010), we would do well to remember, following Foucault, that while force is nearly always the province of the state, power can be more diffuse.

While Sletto makes no use of Lefebvre's (2009b) term autogestion, I suggest that it is useful to think about how it applies to this case. Autogestion can be described as antithesis to state control, with the loose translation as democratic self-management. In contrast to Foucault's notion of governmentality, a term used to describe the tactics of governing a population or the self, autogestion inverts the power relationship by suggesting that self-governance comes from the self and collectives, rather than any set of social norms. Lefebvre makes the claim that rather than reformist (socialist) or revolutionary (dictatorship of the proletariat) politics, we should be seeking a politics of autogestion that is liberatory and democratic. When this is run through the claim that space is political, control of space through territorialization becomes a form of action that can open opportunities for democratic self-governance, and therefore is worthy of further analysis. In this formulation, territorialization becomes an iterative aspect of resistance that takes the form of claims to self-governance, while also resisting other territorializations. The result is an incomplete 'territory of resistance' that is a space of active territorialization. 
27 As can be seen from the above, Marine Protected Areas are of course embedded within the relation of the nation-state to its territorial waters. They are however part of a broad historical process of territorializing the ocean that occurred unevenly over time. While the modern history of the notion of territory is based on the idea of a sovereign's control of its holdings, there is presently a debate around the role that conservation plays in asserting the right of the sovereign. Brockington, Duffy, and Igoe (2008) have pointed to the multiple ways in which conservation policy is currently enacted to offset the ways in which capitalist social relations have degraded the environment, and posited that territorial assertions in the form of conservation spaces have increased with increased expansion of neoliberal markets. Viewed this way, conservation areas in the ocean can be seen as both an assertion of territorial control, and a way to offset the second contradiction of capitalism (O'Connor, 1996) which externalizes environmental costs. Yet these externalities are not evenly distributed, nor are the effects of imposed conservation regimes. People who lose access to resources can and do try to reassert rights to control of those resources, as well as the spaces where said resources are found. While these counter-claims cannot be said to be a sovereign territory, they can however be framed as an attempt at territorialization. This then begs the question, what is the relationship between conservation discourses and territorialization, and how might these be transformed?

\section{A Bahamian MPA Design}

I wish to present a short case, which will also be expanded in forthcoming papers. I have spent a number of years studying a proposed network of MPAs in the Exumas, Bahamas. The authors of the proposal use benthic habitat conditions as the determinate variable for MPA site location (Stoner, Hixon and Dahlgren, 1999). The stated assumption was that representative habitat would protect a representative ecology. After appropriate sites were determined using habitat, the sites were weighted with a number of social variables. The variables considered weighed the presence of an established community, the loss of cash economic activity from fishing, and a rather thin metric of support for conservation (requiring a single individual). These weights were assigned a 1 for less benefit, and 3 for high benefit, meaning that larger numbers indicate more suitable sites for locating an MPA. However, because the determinate variable was the habitat, the social science in this case seems to be included as an addon, a further metric the marine biologist authors of the report hoped would contribute to the success of creating a network of "nature" reserves. Further, the assumption was made that the fishers utilized the ocean as a source of resources for exchange on the market, without consideration of other exploitive uses, such as subsistence. It also appears that none of these variables were fully ground-truthed, and they were instead used to add to the strength of the ecological variables of benthic ecosystem types through statistical weighting.

It is worth noting that in addition to the above named social variables, a score of three could be achieved in the category of "Community Benefits" if, regardless of other factors, the proposed site had "sociopolitical uniqueness," indicating that other social variables could be reduced in weight for political considerations. This score was weighted based on whether a proposed site was near "existing parks, research laboratories, or educational facilities" (Stoner, Hixon and Dahlgre 1999, p. 8). This 
factor provides a benefit accrued to science. However, it can then preempt the metric of economic loss from losing the right to fish. It transforms the community in question from a locally situated subsistence fishery, into the wider notion of mankind, and assumes that scientific research will accrue benefits for local people.

This last variable of "Community Benefit" created problems in the Exuma Islands of the Bahamas, where the Caribbean Marine Research Center (CMRC) was based on Lee Stocking Island. The proposed MPA for the western end of Great Exuma encompassed both Lee Stocking Island, and the large inhabited Cay of Barratarre. If this MPA were to go into effect, it would provide a nearby research testing ground for visiting scientists, but it would also have excluded all fishing activities by the people of Barratarre.

Interviews with interns working at the CMRC in 2002 provided evidence that they were enforcing the proposed MPA preemptively, as they were pulling fish traps out of the water within the boundaries of the proposed MPA. While it is unclear if this was official policy of the CMRC, the result was to effectively create a territory for the exclusive use of scientists. This created tensions with the owners of the fish traps, and led to accusations that the scientists were stealing fish for personal consumption. However, this particular case illustrates that MPAs are not only about conservation. Rather than a just no-take zone, this particular MPA is a space that is exclusively for the use of scientists. The space becomes a territory in which only scientists operate, from which they can exclude other people. Whether their research activities involves extraction is beside the point, or even whether fish are present, as the MPAs restrict the entry of all other people, and thus provides the appearance that scientists are trying to claim the sea as their own.

The problems created by these MPAs failed to fully reckon with the social issues in play. It has resulted in a long series of debates and negotiations, with little progress on the arguably important goal of protecting fishery resources for an archipelagic nation. By failing to account for subsistence activities in economic valuations, the designers designated entire communities as non-fishing, despite the fact fishing is the primary means of obtaining household protein for many people. Further, the variable that identified "support for conservation" failed to ask what form that conservation should take. In trying to create a quantifiable analysis, the MPA proposal oversimplified the social relations at play in many small communities in the Bahamas, and in fact introduced scientists as competitors for fishery resources who can assert a territorial control over MPAs.

In interviews conducted with residents of the Exumas from 2001-2010, a different territorial claim came into being. While the initial protests were against the taking of "our sea," this term was initially used in contexts that suggested locally accessed fishing grounds which were effectively open to all citizens. However, by 2009 people in the Exumas were adopting a different language, and asking how to possibly gain control of the local MPAs. In effect, they were asking to take control of conservation efforts, moving from language that expressed an economic claim, to one that would create a territory for local people. While the people reject the idea of a no-take marine reserve, they are offering a counter proposal that creates MPAs that allow for subsistence fishing, and no more. In Barratarre, they are still hostile to the takeover attempted by the marine scientists, but they want a place at the table when it comes to management decisions. Rather than asserting a traditional territorial claim, they are asking for a new sub-national territory to be created for use and stewardship. 


\section{Moving Forward: Considering the MPA as Territory}

MPAs allow the state to further police waters that are technically already under territorial control. In this scenario, only the territoriality of the state is acknowledged. Discursively, the ocean is held to be a state space reserved for use by citizens of the nation-state, but the state is acknowledged as having regulatory power. If for example, the MPA is structured as a no-take zone, rules can be adopted for the protected space that prohibits all entry (BEST, 2002). This transforms a territorialized, but relatively open access portion of the sea into a space that only the state may enter, and this prohibition against entry creates what I call a 'territory of exclusion'. In the most extreme case, a no-take MPA changes navigational routes and creates a sovereign space that is similar to withdrawn protected areas on land. Even MPAs that permit activities such as snorkeling or limited fishing activity can be viewed as an extension of state power into the ocean, as these rules will still be policed (illustration 1).

Illustration 1 - MPAs as Policed Territory

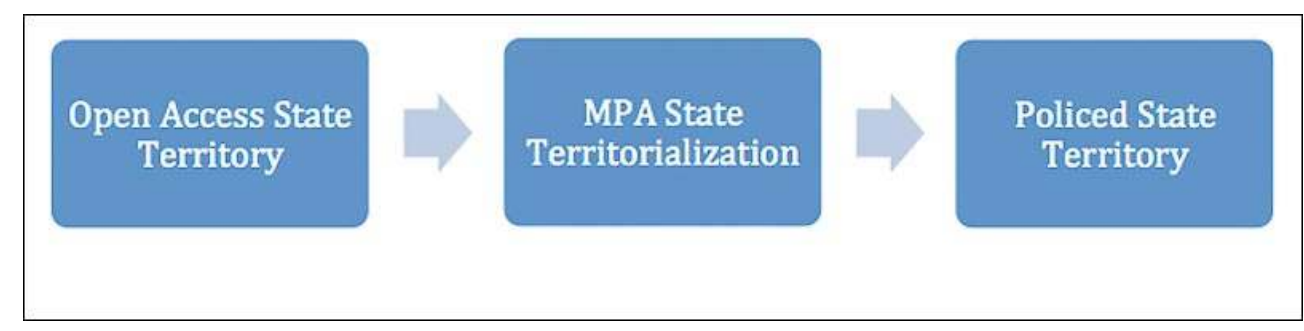

In this case, the MPA produces a more robust territorial formation for the state that restricts access in places that were previously more weakly territorialized. This is not unexpected precisely because as part of state territory, the sovereign right to police is understood within the discourses of conservation practice. This particular form of MPAs as a territorializing construct has been found to be more successful in contexts where the state has a well developed military-industrial complex (Mora et al., 2009). However, in less developed contexts, MPAs are more successful in cases where the conservation area intersects with other territorialities.

The case of a sub-altern territory provides the second example of possible ways that MPAs territorialize, and it has two possible ways that state power can be reconfigured through creating an MPA. In some cases, such as the Miskito Coast or the Seri Indians in northwestern Mexico, the ecosystems were targeted for protection using an MPA by the state, due to ecosystem quality (Nietschmann, 1997; Sanchirico et al., 2003). However, in these cases the ecosystem health is a product of historic indigenous management strategies, and an indigenous territory existed that the MPA would replace and overwrite. In these particular cases, the MPA works as a reterritorialization to inscribe the waters as the territory of the nation-state, rather than the territory of a colonized people. However, in the two cases above, the resistance to an exclusionary territory created by an MPA produced a different territorial formation. Because it was shown that the management techniques of the indigenous people were responsible for ecosystem health, this traditional ecological knowledge was eventually put into the management plans for the MPAs, along with recognition of indigenous claims to territory in the ocean. This then results in a territorialization, that through 
the recognition of the rights of people who make counter-claims to the territory of the state, creates a 'territory of inclusion' that affirms the rights of people who could have been displaced.

The space was re-territorialized by the state as a grant that recognized territorial claims beyond the state, yet within the legal framework of state territory. The MPA worked against the power of the state in terms of exclusive control over its territorial waters; yet, it still produced a territory that meets the needs of the state in terms of environmental protection. In the case of the Miskito Coast and the Seri Indians, the MPA worked to simultaneously deterritorialize and re-territorialize in an affirmation of indigenous territory, and power has been devolved to a colonized people with territorial claims in the ocean. However, while these cases provide example of a successful defense of territory, there is a second possible outcome. If the state created an MPA overlaying indigenous territory, but ignored the prior claims, this would result in a loss of the indigenous territory leaving only the state territorial formation of the first case (illustration 2). This does however lead me to the third model I wish to present in the ways that MPAs territorialize the oceans, and that is as a driver of reterritorialization.

Illustration 2 - MPA as an Overwriting Territorialization

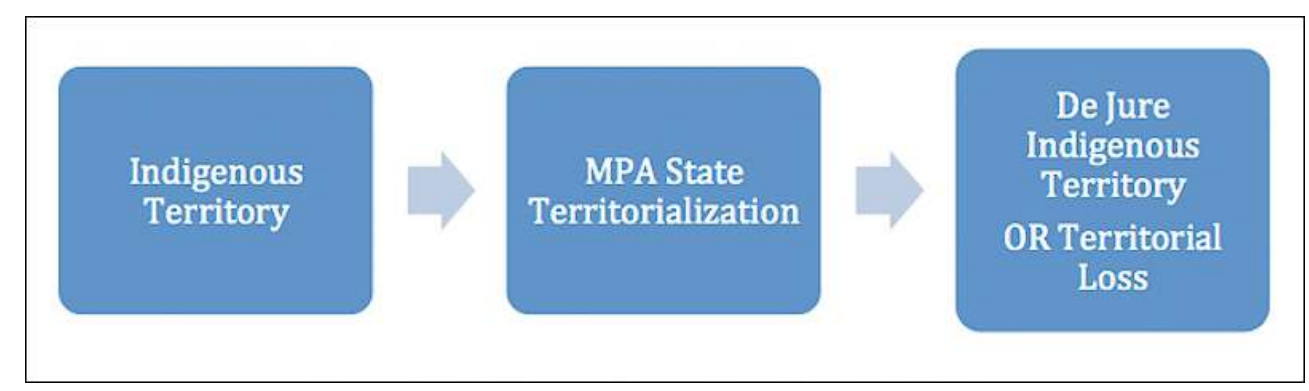

In the third possible case, there is little-to-no historical territorialization of the waters in question outside of the notion of state territory, as existed in the case of the Exumas. It functions as a space that is open access for the citizens of the nation, and the existing territoriality is that of a nation-state patrolling its waters for violations of international treaty or violations of national law. Because the ocean is an open access space of the state, MPAs can be proposed that partition the ocean as a part of the sovereign right to control resources. Thus far, it appears that the first case should apply. However, in this case, a portion of the population who previously had no territorial claims to the sea contests the withdrawal. While it is tempting to describe this as a case of NIMBYism, or perhaps an economic claim, in this instance, the process of trying to establish a protected area calls forth a territorial claim where none existed before. While livelihood is definitely a part of this resistance, the discourse that is constructed in this instance operates on multiple scales to re-territorialize the ocean as "our sea" in response to an MPA proposal. While the dominant scale deployed by local people is always focused on local context, this territorialization also engages the issue of conservation on a national scale by arguing for local practices in consideration of national policy. Local people make claims to the right to use and control local waters, but may also scale up to claim that conservation policy should reflect local practices that led to the ecosystem health that is to be protected. This instance of territorialization is interesting precisely because while it resembles the claims cited in 
the second case, there is no previously existing territory to be overwritten by an MPA (illustration 3).

Illustration 3 - MPA as Agent of Re-territorialization

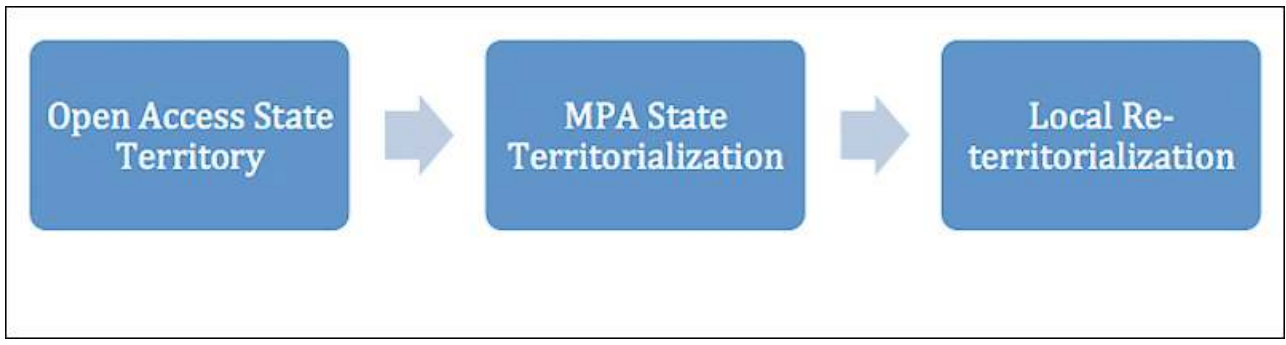

The potential politics that arise from this third case of territorialization and reterritorialization are interesting, and there are a number of possible results. The first possibility is that the state follows the first scenario of MPA territorialization, and ignores the counter-claims to the spaces in question and implements an MPA as an extension of state power. In this scenario, the state may target the MPA for heavy enforcement in order to prevent local people from acting on their territorializing claims and effect a police zone. However, in the case of decreased enforcement capacity, such as that found in much of the Global South, and certainly in the Exumas, Bahamas, there is a high likelihood that the re-territorializing claims of the local people will result in outlaw behavior as they seek to sustain their historic livelihood strategies (Ogden, 2011). Interviews in the Bahamas in 2009-2010 suggested that not only were people fishing in a marine park, but they would also continue to fish in the proposed MPAs. A second possibility is that ongoing resistance will cause conservation to fail due to organized activity against the MPA. People may petition the government to relocate the MPA, and politicians may try to gain political capital by adopting the petition of the local people. This would then either move the problem to a new community, or in the worst case become the end of protective strategies that use territorial enclosures.

There is however a third possibility that could result from this re-territorialization that could have positive outcomes. In this scenario, the state takes advantage of the territorial claims made by local people to create an MPA that incorporates these claims. This is a similar result to the case of overwriting territorialization, with the exception that there is no territory to be overwritten. Instead, there is a territorialization that only comes into existence when the state attempts to withdraw an area for conservation purposes. This is precisely what the fishers of the Exumas are asking for, the chance to control their local ocean and protect it from degradation. Within all these possibilities, the active struggle of territorialization plays out in a 'territory of resistance,' whether the outcome recognizes that territory or not.

This is a possible liberatory moment. People who have conservation imposed upon their livelihoods often suffer in ways that disrupts their economic well being because conservation practices are responding to over-development in ways that serve to further disempower local people (Smith, 1990; Butcher, 2007; Brockington, Duffy,, and Igoe, 2008). Yet, while MPAs have a goal of changing human activity, as we have seen above, they invoke certain social relations about the control of space. In other words, they call forth territories: a territory for scientific practice; a territory for local people; a territory of the state deployed by managers and experts to both offset and promote 
the effects of capitalist overconsumption. While some theorists have argued that territory is the exclusive province of the state in the modern juridical framework (Elden, 2009), MPAs, and perhaps all conservation areas, question this assumption through the ways in which they create bounded defensible areas for diverse purposes. The social groups that seek to use these spaces perform in a territorial fashion, arguing for exclusive use of the space. The question then remains, if MPAs produce effects that cause them to appear to be a territory that can exist beyond the level of the state (although within the jurisdiction of the state), can they be effectively used as a form of resistance as well?

\section{Conclusion}

This new territorialization as political practice links the concepts of autogestion and governmentality. By making territorial claims to the ocean as a tactic of resistance to MPAs, people are seeking to deploy power across space in ways that result in selfmanagement. Should the state decide to recognize said territorializations, this could lead to an MPA as a territorial formation that goes beyond the notion of communitybased management. While community-based management seeks to design conservation in consultation with local people, the logic of the state control of territory tends to prevail. The state consults, but ultimately territorializes the ocean through the creation of an MPA, and has the option to end consultation, should the people fail to govern their conduct within the rules of the state. However, should the state decide to recognize a counter territorialization, and cede both management and territorial control to a local community, it is possible that people will not only seek to enforce their territorialization, but also develop rules of governance that empower them to become environmental stewards. As the case provided by sletto above shows, by inserting into the discourses of control over protected areas the idea that local knowledge is a tool for conservation, this in turn can empower people to become the stewards that the discourse they deploy tells them to be. This is a positive instance of governmentality in which the people create their own conservation discourse in order to manage their own resources.

While this case uses Marine Protected Areas, and the problematic space of the oceans as its subject, there is also the question of wider conservation practice. While the territorialization of the oceans is a recent phenomenon, I have to wonder, can this case be transferred to the land? In my own lifetime, I have met people who both abuse and care for natural resources, with varying claims to ownership, territory, and rights based on historical circumstance and legal status. While community based management is becoming more common in terrestrial conservation areas, it has had some failures, but many more successes. While many of these claims seek a traditional ecological knowledge model, perhaps we as scholars might consider that an assertion of a territorial claim to a space in which conservation is desired could be a powerful tool to achieve multiple goals.

Acheson J. M., 2006. Institutional Failure in Resource Management. Annual Review of Anthropology, 35 , p. 117-134.

Agnew J., 1994. The Territorial Trap: The Geographical Assumptions of International Relations Theory. Review of International Political Economy, 1 (1), p. 58-30. 
Agrawal A., 2000. Community and Natural Resource Conservation. In F. Gale and R. M. M'Gonigle (eds.), Nature, Production. Power: Towards an Ecological Political Economy, Northhampton, MA, Edward Elgar Publishing.

Agrawal A., 2005. Environmentality: Technologies of Government and the Making of Subjects. Durham and London, Duke University Press.

Agrawal A., Gibson C. C., 1999. Enchantment and disenchantment: The role of community in natural resource conservation. World Development, 27 (4), p. 629-649.

Beddington J. R., Agnew D. J., Clark C. W., 2007. Current Problems in the Management of Marine Fisheries. Science, 1316 (22 June 2007), p. 1713-16.

Berkes F., 1999. Sacred Ecology: Traditional Ecological Knowledge and Resource Management. Philadelphia, PA, Taylor and Francis.

BEST, 2002. Bahamas Environmental Handbook, ed. S. Bahamas Environment, and Technology Commission. Nassau, Bahamas, Ministry of Agriculture and Fisheries.

Broad K., Sanchirico J. N., 2008. Local perspectives on marine reserve creation in the Bahamas. Ocean and Coastal Management, 51 (11), p. 763-771.

Brockington D., Duffy R., Igoe J., 2008. Nature unbound: conservation, capitalism and the future of protected areas. London, Sterling, Va., Earthscan.

Butcher J., 2007. Ecotourism, NGOs and Development. London and New York, Routledge.

Castilla J. C., 1993. Humans: Capstone strong actors in the past and present coastal ecology play. In M. J. McDonnell and S. T. A. Pickett (eds.), Humans as Components of Ecosystems, Berlin, SpringerVerlag, p. 158-162.

Castree N., 2005. Nature. London, New York, Routledge.

Christie P., McCay B. J., Miller M., Lowe C., White A., Stoffle R. W., Fluharty D., McManus L., Chuenpagdee R., Pomeroy C., Suman D., Blount B., Huppert D., Eisma R.-L., Oracion E., Lowry K., and Pollnac R., 2003. Towards Developing a Complete Understanding: A Social Science Research Agenda for Marine Protected Areas. Fisheries, 28 (12), p. 22-26.

Clark G. L., Dear M., 1984. State Apparatus: Structures and Language of Legitimacy. Winchester, MA, Allen and Unwin Inc.

Costello C., Gaines S. D., Lynham J., 2008. Can Catch Shares Prevent Fisheries Collapse? Science, 321 (5896), p. 1678-1681.

Cronon W., 1995. The trouble with wilderness: Or, getting back to the wrong nature. In W. Cronon (ed.), Uncommon Ground: Rethinking the Human Place in Nature, New York, W. W. Norton \& Co, p. 69-90.

Deleuze G., Guattari F., 1987. A Thousand Plateaus: Capitalism and Schizophrenia. Minneapolis, University of Minnesota Press.

Elden S., 2009. Terror and Territory: The Spatial Extent of Sovereignty. Minneapolis, University of Minnesota Press.

Elden S., 2010. Land, terrain, territory. Progress in Human Geography, (34).

Elliott G., Mitchell B., Wiltshire B., Manan I. A., Wismer S., 2001. Community participation in marine protected area management: Wakatobi National Park, Sulawesi, Indonesia. Coastal Management, (29), p. 295-316. 
Glassner M. I., 1990. Neptune's domain: a political geography of the sea. Boston: Unwin Hyman.

Gordon H. S., 1954. The Economic Theory of a Common Property Resource: The Fishery. The Journal of Political Economy, 62 (2), p. 124-142.

Gottmann J., 1973. The Significance of Territory. Charlottesville, VA, The University Press of Virginia.

Hannesson R., 2004. The privatization of the oceans. Cambridge, Mass., MIT Press.

Haraway D. J., 1991. Simians, cyborgs, and women: the re-invention of nature. London, Free Association.

Hardin G., 1968. The Tragedy of the Commons. Science, 162 (1968), p. 1243-1248.

Harvey D., 2003. The New imperialism. Oxford, Oxford University Press.

Igoe J., 2004. Conservation and globalization: a study of the national parks and indigenous communities from East Africa to South Dakota. Belmont, CA, USA, Thomson/Wadsworth.

Johnsen J. P., Holm P., Sinclair P., Raanes S. A., 2004. The Coming of the Cyborg Fish: How resource management is made possible. Trondheim, Norway: Center for Rural Research.

Johnson C., 2004. Uncommon Ground: The 'Poverty of History' in Common Property Discourse. Development and Change, 35 (3), p. 407-433.

Kaiser M. J., 2005. Are marine protected areas a red herring or fisheries panacea? Canadian Journal of Fishery and Aquatic Science, 62, p. 1194-1199.

Krech S., 1999. The ecological Indian : myth and history. New York, London, W.W. Norton,1st ed..

Lefebvre H., 1991. The Production of Space. Malden, MA, Blackwell Publishing.

Lefebvre H., 2009a. Reflections on the Politics of Space. In N. Brenner and S. Elden (eds.), State, Space, World: Selected Essays, Minneapolis, MN, University of Minnesota Press.

Lefebvre H., 2009b. Theoretical Problems of Autogestion. In N. Brenner and S. Elden (eds.), State, Space, World: Selected Essays, Minneapolis, MN, University of Minnesota Press.

Mansfield B., 2001. Thinking through scale: the role of state governance in globalizing North Pacific Fisheries. Environment and Planning A, 33, p. 1807-1827.

Mansfield B., 2004. Neoliberalism and the oceans; "rationalization," property rights, and the commons question. Geoforum, (35), p. 313-326.

Mansfield B., 2005. Beyond rescaling: reintegrating the 'national' as a dimension of scalar relations. Progress in Human Geography, 29 (4), p. 458-473.

Mansfield B., 2007a. Privatization: Property and the Remaking of Nature-Society Relations. Antipode, 39 (3), p. 393-405.

Mansfield B., 2007b. Property, Markets, and Dispossession: The Western Alaska Community Development Quota as Neoliberalism, Social Justice, Both, and Neither. Antipode, 39 (5), p. 479-499.

McCay B. J., 1987. The Culture of the Commons: Historical Observations on Old and New World Fisheries. In B. J. McCay and J. M. Acheson (eds.), The Question of the Commons: The Culture and Ecology of Communal Resources, Tucson, AZ, University of Arizona Press.

McCay B. J., Acheson J. M. (eds.), 1987. The Question of the Commons: The Culture and Ecology of Communal Resources. Tucson, AZ, University of Arizona Press. 
McCay B. J., Jentoft S., 1998. Market or community failure? Critical perspectives on common property research. Human Organization, 57 (1), p. 21-29.

Mehta J. N., Kellert R., 1998. Local attitudes towards community-based conservation policy and programmes in Nepal: A case study in the Makalu-Barun Conservation Area. Environmental Conservation, 25 (4), p. 320-333.

Mora C., Myers R. A., Coll M., Libralato S., Pitcher T. J., Sumaila R. U., Zeller D., Watson R., Gaston K. J., Worm B., 2009. Management Effectiveness of the World's Marine Fisheries. PLoS Biol, 7 (6), e1000131.

National Research Council, 2001. Marine Protected Areas: Tools for Sustaining Ocean Ecosystems. Washington D.C., National Academy Press.

Neumann R. P., 1997. Primitive Ideas: Protected Area Buffer zones and the Politics of Land in Africa. Development and Change, 28, p. 559-582.

Neumann R. P., 1998. Imposing Wilderness: Struggles over Livelihood and Nature Preservation in Africa. Berkeley, CA, University of California Press.

Nietschmann B., 1997. Protecting indigenous coral reefs and sea territories, Miskito Coast, RANN, Nicaragua. In S. Stevens (ed.), Conservation through cultural survival: Indigenous peoples and protected areas, Washington DC, Island Press.

Nietschmann B. Q., 1973. Between Land and Water. New York, Seminar Press.

Nowlis, J. S., Friedlander A., 2004. Design and Designation of Marine Reserves. In. J. Sobel and C. P. Dahlgren (eds.), Marine Reserves: A Guide to Science, Design, and Use, Washington, DC, Island Press.

O'Connor J., 1996. The Second Contradiction of Capitalism. In T. Benton (ed.), The Greening of Marxism, New York and London, Guilford Press.

Ogden L. A., 2011. Swamplife: People, Gators, and Mangroves Entangled in the Everglades. Minneapolis, University of Minnesota Press.

Pannell S., 1996. Homo Nullius or 'Where Have All the People Gone'? Refiguring Marine Management and Conservation Approaches. The Australian Journal of Anthropology, 7 (1), p. 21-42.

Pretty J., Ward H., 2001. Social capital and the Environment. World Development, 29 (2), p. 209-227.

Ribot J. C., Peluso N. L., 2003. A theory of access. Rural Sociology, 68 (2), p. 153-181.

Robbins P., 2003. Fixed Categories in a Portable Landscape: The Causes and Consequences of Land Cover Categorization. In K. Zimmerer and T. J. Bassett (eds.), Political Ecology: An integrative approach to geography and environment-development studies, New York, The Guilford PRess.

Robbins P., 2004. Political ecology : a critical introduction. Malden, MA, Blackwell Pub.

Roberts C., Halpern B. S., Palumbi S. R., Warner R. R., 2001. Designing Marine Reserve Networks: Why Small Isolated Protected Areas Are Not Enough. Conservation Biology in Practice, 2 (3), p. 13-19.

Rome A. W., 2001. The bulldozer in the countryside : suburban sprawl and the rise of American environmentalism. Cambridge, New York, Cambridge University Press.

Sack R. D., 1986. Human territoriality: its theory and history. Cambridge [Cambridgeshire], New York, Cambridge University Press.

Safina C., Rosenberg A. A., Myers R. A., Quinn T. J. I., Collie J. S., 2005. U.S. Ocean Fish Recovery: Staying the Course. Science, 309 (29 July 2005), p. 707-708. 
Sanchirico J. N., Stoffle R., Broad K., Talaue-McManus, 2003. Modeling Marine Protected Areas. Science, 4 (July 2003), p. 47-49.

Sapp J., 1999. What is natural?: coral reef crisis. New York, Oxford, Oxford University Press.

Sletto B. I., 2005. A swamp and its subjects: conservation politics, surveillance and resistance in Trinidad, the West Indies. Geoforum, 36, p. 77-93.

Smith N., 1990. Uneven development: nature, capital, and the production of space. Oxford, UK, Cambridge, Mass., USA, B. Blackwell.

Sobel J., Dahlgren C. P. (eds)., 2004. Marine Reserves: A Guide to Science, Design, and Use. Washington, DC, Island Press.

Spieles D., J. 2010. Protected Land: Disturbance, Stress, and American Ecosystem Management. New York, Springer.

St. Martin K., 2001. Making Space for Community Resource Management in Fisheries. Annals of the Association of American Geographers, 91 (1), p. 122-142.

St. Martin K., 2006. The impact of "community" on fisheries management in the US Northeast. Geoforum, 37 (2), p. 169-184.

Steinberg P. E., 2001. The Social Construction of the Ocean. Cambridge, Cambridge University Press.

Stevens S., 1997. Introduction. In S. Stevens (ed.), Conservation through cultural survival: indigenous peoples and protected areas, Washington D.C., Island Press.

Stoffle R. W., 1986. Caribbean Fisherman Farmers: A Social Assessment of Smithsonian King Crab Mariculture, 141. Ann Arbor, MI, Survey Research Center, Institute for Social Research, The University of Michigan.

Stoffle R. W., 2001. When fish is water: Food security and fish in a coastal community in the Dominican Republic. In J. R. McGoodwin (ed.), Understanding the Cultures of fishing communities: a key to fisheries management and food security, Fisheries Technical Paper 401, Rome, FAO.

Stoffle R. W., Minnis J., 2007. Marine protected areas and the coral reefs of traditional settlements in the Exumas, Bahamas. Coral Reefs, 26 (4).

Stoffle R. W., Minnis J., Murphy A., Van Vlack K., O'Meara N., Smith T., McDonald T., 2010. TwoMPA Model for Siting Marine Protected Areas: A Bahamian Case. Coastal Management, 38 (5), p. 501-517.

Stoner A. W., Hixon M. A., Dahlgren C. P., 1999. Scientific Review of the Marine Reserve. Network Proposed for the Commonwealth of the Bahamas by the department of Fisheries.

Vandergeest, P., Peluso N. L., 1995. Territorialization and state power in Thailand. Theory and Society, 24, p. 385-426.

Walker P. A., 2005. Political ecology: where is the ecology? Progress in Human Geography, 29 (1), p. 73-82.

Wolf C., 2003. Environmental Ethics and Marine Ecosystems: From a "Land Ethic" to a "Sea Ethic". In D. G. Dallmeyer (ed.), Values at Sea: Ethics for the Marine Environment, Athens and London, The University of Georgia Press.

Worm B., Barbier E. B., Beaumont N., Duffy J. E., Folke C., Halpern B. S., Jackson J. B. C., Lotze H. K., Micheli F., Palumbi S. R., Sala E., Selkoe K. A., Stachowicz J. J., and Watson R., 2006. Impacts of Biodiversity Loss on Ocean Ecosystem Services. Science, 314 (5800), p. 787-790. 
Zimmerer K., 1994. Integrating the new ecology in human geography. Annals of the Association of American Geographers, 84, p. 108-125.

Zimmerer K., 2000. The Reworking of Conservation Geographies: Nonequilibrium Landscapes and Nature-Society Hybrids. Annals of the Association of American Geographers, 90 (2), p. 356-369.

\section{NOTES}

1. I find it interesting that Nietschmann conceptually deploys both territory and tenure as spatial imaginaries. Each invokes a different series of rights and responsibilities under modern juridical regimes. Tenure would suggest a property relation involving title, whereas territory suggests a sovereign jurisdictional institution without necessarily clear property rights.

\section{AUTHOR}

\section{FLETCHER CHMARA-HUFF}

Fletcher Chmara-Huff, tuf33671@temple.edu, Temple University, Department of Geography and Urban Studies, Philadelphia, PA. 